the 'fixation' of nitrogen of the air by the synthesis of complex organic nitrogen compounds. Vinogradsky's discovery of the relation of atmospheric nitrogen to soil bacteria represents a new epoch in biology and agriculture.

From different aspects, the work of V. Paladin and A. Bach led to an understanding of the biochemical processes forming the basis of the respiration of plants and animal cells.

From its inception the evolutionary teaching of Charles Darwin had ardent protagonists in Russia among philosophers and scientific men such as Pisaryev, Timiryazev, Mechnikov, and, later, Mensbir and A. N. Severtsov. At the very beginning of the twentieth century, simultaneously with Sedgwick, A. N. Severtsov widened and deepened Darwin's teachings by his work on the study of the relationship between the individual and the evolutionary development of organisms.

All these achievements of Russian biologists during the nineteenth century form the basis for the manysided development of science in Russia which has characterized recent years. Scientific men of the U.S.S.R., fully aware of their debt to their people, always remember the words of one of their teachers, I. P. Pavlov, who said: "Our fatherland opens vast fields to scientists, and it is necessary to repay the debt; science is generously introduced into the life of our country - to the last degree, generously . . . and for us it is a matter of honour-to fulfil the great hopes that our country places on science".

\section{ASPECTS OF INDIAN INDUSTRIAL DEVELOPMENT}

$\mathrm{P}$ RIOR to the War of 1914-18, Indian industrial development, except for the textile industries based on cotton and jute, were on a minor scale. The great Tata iron and steel works at Jamshedpur were still in process of erection and it was not until after 1917 that it was in a position to make a major contribution to the war effort. Public opinion had already forced the Government of India to recognize the desirability for a more rapid industrial development, resulting in the appointment of the Indian Industrial Commission. Unfortunately, many of the recommendations made in the Commission's valuable report were not implemented, nor was much attention paid to the suggestions for the development of chemical and metallurgical industries made in the pamphlets issued by the Indian Munitions Board. The temporary impetus resulting from the War soon died down and almost the only large-scale industry based on science which developed during the next two decades was that of soap and related products, manufactured by modern methods, in the Tata Oil Mills. It would serve little purpose, nor would it indeed be profitable, to discuss the varied causes for this, but one of the main causes has undoubtedly been lack of adequate technical advice and of skilled labour.

Now, with another war of world-wide range, the opportunity has once more arrived for India to become industrialized, and this time we feel there can be no relapse. As a supply centre for the Near and Far East she occupies a key position. This time it is possible for the advance to be planned and to be based upon solid scientific research. It is true that for many years now, cotton, jute and lac have had their research organizations, and therein lies probably the cause of their prosperity, but planned industrial research on the many problems of the chemical and metallurgical industries under tropical conditions has been almost completely lacking. This gap has now been filled by the new Board of Scientific and Industrial Research. A further guarantee that the fundamental chemical industries will be established on an adequate scale is furnished by the decision of Imperial Chemical Industries, Ltd., to form an Indian company. We may anticipate that this will meet with success equal to that achieved by the similar organizations in South Africa and Australia.

Rich as India is both in mineral and plant products, she is, like other countries, by no means fully selfsufficient. The main coal deposits are situated far from the Punjab, Bombay and Madras, although this lack of fuel is to some extent compensated by cheap electricity generated by water-power. A further fundamental requirement is sulphur for the manufacture of sulphuric acid, since even now it is true that the consumption of sulphuric acid provides an index of a country's industrial development. India drew her supplies of sulphur almost entirely from enemy countries, Italy and Japan, and although the immediate war-time needs are being met from the comparatively small deposits in Baluchistan, these, besides being difficult of access, would be quite inadequate in normal times. A nearby and practically inexhaustible source of supply could be made available by the desulphurization of the waste gases from the Anglo-Iranian oil-fields. In an interesting paper, Forrester and Gilbert (Trans. Min., Geol. and Metal. Inst. India, 37, 61-168; 1941) have surveyed some aspects of chemical and metallurgical industries as applied to Indian conditions, and they suggest that considerable quantities of sulphur dioxide could be recovered from the Indian Copper Corporation's smelting plant. This source, were it developed, would, however, only very partially meet India's normal requirements, and other sources will have to be found. The former possibility would appear to be worthy of careful consideration, since it would at the same time give a gas suitable for the manufacture of a highclass carbon black.

Whereas the metallurgical industries based on iron are already developed on a large scale in India, no attempt has been made so far to establish the manufacture of either aluminium or magnesium, although much has been written on the subject. For the manufacture of the former, both the necessary raw materials and cheap electrical power are available, so that presumably lack of capital and of adequate scientific assistance have caused the delay in the establishment of this essential industry. The growing importance of the lighter alloys would justify also the manufacture of magnesium, for which the separation of magnesium salts from sea water by modern methods would provide the necessary material.

In their paper, referred to above, Forrester and Gilbert tabulate a long list of coal-tar products which are now being made in India; but with the relatively small and scattered gas plants which are in operation, it would appear doubtful if a large-scale industryand to be economically successful it must be on a large scale-can be developed from coal-tar. It would seem that in India a synthetic chemical industry 
must be based on different materials, and for such new developments she is not ill-situated. There are in Assam and in the Punjab developed sources of petroleum, and even if these fields are relatively small as compared to those of Russia and America, they should provide sufficient materials for the manufacture of chemicals which recent research has shown to be readily obtainable from the oil and gas. It seems likely also that the manufacture of calcium carbide will soon be undertaken, and if this were done, acetylene would be available from which, as has been found in Canada, a host of subsidiary chemical industries can be developed. Finally, thanks to the research work initiated by Barber at Coimbatore and since extended by many other workers, cane sugar is now produced on a very large scale. By well-established processes, sugar provides a source of a great variety of products such as alcohol, acetone, butanol, citric and gluconic acids.

In India, a chemical industry based upon petroleum, sugar and calcium carbide might prove to be far more economical than one based upon coal tar. Development on these lines will necessarily involve much fundamental research and may appear to be speculative at the present time, but it seems to be more likely to lead to success than one based on older and well-established methods. It would certainly be profitable for the younger chemists now being trained in India to devote some of their energy and skill to a consideration of these problems. A further large field for. research is to be found in the development of India's reserves of cellulose. In Sweden the exigencies of war have emphasized how very valuable a raw material this is. In the post-war years, we may anticipate that India will lead in this and in other fields of technical research.

\section{PIONEERS OF REFRIGERATION*}

\section{By ENG.-CAPT. EDGAR C. SMITH, O.B.E., R.N.}

$\mathrm{D}$ URING the greater part of the nineteenth century, there was a considerable trade in natural ice, and ice cut from Wenham Lake, near Boston, in the United States, was known in many parts of the world. Some of this ice came to Great Britain, which also obtained supplies from Greenland and Norway. It was this trade which led the famous engineer, Richard Trevithick, in 1828 to suggest to his friend, Davies Gilbert, that ice could be made by the compression and expansion of air.

The earliest apparatus for making artificial ice was that of William Cullen, who described his water evaporating device so long ago as 1755 , while he still held the chair of chemistry at Glasgow. He was the first of many Scotsmen to further the practice of artificial cooling, and about half a century after he had made his evaporation apparatus, John Ieslie, while holding the chair of mathematics at Edinburgh in 1810 , devised his water absorption apparatus, in which water evaporated in a vacuum was absorbed by sulphuric acid. Writing in the seventh edition of the "Encyclopædia Britannica", Leslie referred tó his method of "producing congelation on a large scale" and added that with a proper system of air-pumps,

- Substance of a paper read before the Newcomen Society on March 10. worked by a steam engine of six horse-power, it might be possible in the climate of London to produce ice at the rate of a ton a day. The noed for means of cooling was felt most in breweries, and the patents taken out for cooling worts and other liquids are very numerous. The first of such patents is that taken out in 1819 by Robert Salmon, the ingenious mechanist to the Duke of Bedford, at Woburn Abbey, in conjunction with William Warrell. This patent was No. 4331 of January 15, 1819.

As is well known, the three principal types of refrigerating plant which have been used on a large scale are the ammonia absorption machine; the air refrigerating machine, first visualized in a crude manner by Trevithick; and the vapour compression machine, the first example of which was made in an East London engineering shop for the American engineer, Jaeob Perkins (1766-1849), according to his patent No. 6662 of August 14, 1834. Though a trial was made with the Perkins machine, it was not very successful and the inventor, having many other things on hand, did not pursue the matter.

About ten years later, the idea of using machines for cooling air in sick-rooms, hospitals, etc., occurred almost simultaneously to the American physician, James Gorrie (1803-55), of Apalachicola, Florida, and to the Astronomer Royal for Scotland, Charles Piazzi Smyth (1819-1900). Both these men spent about ten years trying to develop their ideas, and on May 6, 1851, Gorrie secured the United States patent No. 8080, the first patent for an air refrigerating machine. Smyth in his work had the assistance of Rankine, and of James Stirling, the brother of the Rev. Robert Stirling, who had invented the hot-air engine. Though Smyth's proposals were the subject of a report to the Indian Government, nothing came of them. Gorrie, on the other hand, did apparently see some of his plans adopted, but when he tried to get them introduced on a larber scale, his funds failed, his health broke down and he died at the early age of fifty-two. His merits, however, have not been forgotten and his statue now stands in the Statuary Hall, Washington, D.C.

By the time of Gorrie's death, artificial cooling had become a matter of great interest in Australia, where some far-sigkted individuals saw that the surplus meat of the Colonies would readily find a market in Europe if means existed of preserving and transporting it. Among those whom this question stimulated was the Scottish journalist, James Harrison (1816-93), and the Lancashire wool broker and business man, Thomas Sutcliffe Mort (1816-78), both of whom had emigrated to Australia about 1838 . Harrison had a long career as a journalist and at one time edited the Melbourne Age. $\mathrm{He}$ was also the parliamentary representative for Geelong, Victoria, where he had settled. It is said that he corresponded with Faraday and Tyndall, but however this may be, in the 'fifties he began experimenting on ice-making, and in 1855 took out an Australian patent ; then coming to England, he secured patents No. 747 of March 28, 1856, and No. 2362 of September 10, 1857, for a vapour compression machine using ether. His earliest machines were made in Holborn by the German engineers, Siebe Brothers, the founders of the wellknown firm, Siebe, Gorman and Co., Ltd., the first machine being set up at the famous paraffin works of James Young at Bathgate, Scotland, the cradle of the Scottish shale oil industry. Previously, to separate the solid paraffin from the oil, it had been necessary to store the oil in summer and then expose 